\title{
Racemic and Optically Pure Heptahelicene-2-carboxylic Acid: Its Synthesis and Self-Assembly into Nanowire-Like Aggregates
}

\author{
Jiř́i Rybáček, ${ }^{[a]}$ Gloria Huerta-Angeles, ${ }^{[a]}$ Adrian Kollárovič, ${ }^{[a]}$ Irena G. Stará, *[a] \\ Ivo Starý, ${ }^{*[a]}$ Philipp Rahe, ${ }^{[b]}$ Markus Nimmrich, ${ }^{[b]}$ and Angelika Kühnle ${ }^{*[b]}$
}

\author{
Dedicated to Dr. Jiři Závada on the occasion of his 70th birthday
}

Keywords: Arenes / Alkynes / Cyclotrimerisation / Nanostructures / Scanning probe microscopy

\begin{abstract}
Heptahelicene-2-carboxylic acid was effectively synthesised from suitably functionalised naphthalene building blocks. Methoxy-substituted 1,1'-ethyne-1,2-diylbis(2-but-3-yn-1ylnaphthalene) was cyclised in the presence of $\mathrm{CpCo}(\mathrm{CO})_{2} /$ $\mathrm{PPh}_{3}$ to 2-methoxy-7,8,11,12-tetrahydroheptahelicene, which was converted into heptahelicen-2-yl trifluoromethanesulfonate. This reactive intermediate underwent $\mathrm{Pd}(\mathrm{OAc})_{2} /$ dppp-catalysed methoxycarbonylation reaction to provide, after hydrolysis, heptahelicene-2-carboxylic acid. The race-
\end{abstract}

mate was resolved into enantiomers by semipreparative HPLC on a chiral column. The helicity of $(+)-(P)$-heptahelicene-2-carboxylic acid was assigned by correlating its CD spectrum to that of the known $(+)-(P)$-heptahelicene. Racemic heptahelicene-2-carboxylic acid was deposited on calcite $(10-14)$ to undergo self-assembly into nanowire-like aggregates as demonstrated by noncontact atomic force microscopy (NC-AFM).

\section{Introduction}

Non-covalent interactions between $\pi$-electron systems (frequently called $\pi-\pi$ stacking or $\pi-\pi$ interaction) ${ }^{[1]}$ is one of the key elements in the self-assembly of organic molecules and materials and is responsible for their frequently unique properties. ${ }^{[2]}$ The importance of this phenomenon can be demonstrated by numerous examples. Two of them are particularly illustrative: The double helix of the most common B-DNA is stabilised not only by hydrogen bonds between the nucleic bases but also by dispersion and electrostatic forces between the stacked base pairs. If the dispersion forces are zeroed (in an in silico experiment), the helical structure of the nucleic acid collapses to a ladder-like arrangement and is unable to store and transfer genetic information. ${ }^{[3]}$ Furthermore, imaterials science, $\pi-\pi$ interaction plays a fundamental role in the self-assembly of $\pi$-electron systems in the solid state, both in crystals and thin films. ${ }^{[4]}$ Such a key interaction can be found in highly conductive TTF-TCNQ ${ }^{[5]}$ organic metal, in which the compo-

[a] Institute of Organic Chemistry and Biochemistry, v. v. i., Academy of Sciences of the Czech Republic

Flemingovo nám. 2, 16610 Prague 6, Czech Republic Fax: +420-220-183-133

E-mail: stara@uochb.cas.cz stary@uochb.cas.cz

[b] Institut für Physikalische Chemie, Johannes-GutenbergUniversität Mainz

Jakob-Welder-Weg 11, 55099 Mainz, Germany

E-mail: kuehnle@uni-mainz.de

Supporting information for this article is available on the WWW under http://dx.doi.org/10.1002/ejoc.201001110. nents are organised in segregated columnar stacks, ${ }^{[5]}$ or in the herringbone structures of crystalline pentacene; this has attracted enormous attention owing to its remarkably high charge mobility. ${ }^{[6]}$

Although a myriad of $\pi$-electron systems exist, only a small fraction of them have so far been examined to identify new materials for molecular electronics. Non-planar aromatics, such as helicenes, ${ }^{[7]}$ belong to a scarcely explored family of compounds. The striking self-assembly of suitably functionalised helicene quinones into long fibrous aggregates $^{[8]}$ or helically twisted columnar discotic liquid crystals, ${ }^{[9]}$ has already been demonstrated. Supposedly, $\pi-\pi$ interactions within the long corkscrew-shaped assemblies contribute to their unique behaviour in solution or in the solid state. In contrast, the controlled deposition of [7]helicene on $\mathrm{Cu}(111),{ }^{[10]} \mathrm{Cu}(332),{ }^{[10 \mathrm{c}]} \mathrm{Ni}(100)^{[11]}$ or $\mathrm{Ni}(111),{ }^{[12]}$ and hexathia[11]helicene on $\mathrm{Au}(111)^{[13]}$ resulted in the formation of adlayers in which individual helicene molecules lay flat or tilted on the surfaces (with their helix axis adopting an angle of ca. $43-90^{\circ}$ to the substrate plane). However, molecules of hexathia[11]helicene on $\mathrm{Au}(110)$ self-assembled to a certain degree into long chains on terraces, whereas on polycrystalline gold they self-assembled at the step edges. ${ }^{[13]}$ The thin film of tetrathia[7]helicene on $\mathrm{SiO}_{2}$ formed by vapour deposition exhibited a tubular morphology on a micrometre scale, but its thin-film transistor activity was low because of either poor film crystallinity or improper crystal packing. ${ }^{[14]}$ 
Nevertheless, although the formation of the long corkscrew-shaped $\pi$-electron systems is a challenging task, it has possible applications in molecular electronics and nonlinear optics. Helicene aggregates ${ }^{[7]}$ or long individual helicenes ${ }^{[15]}$ are attractive in this regard, because they can inherently combine the $\pi$-conjugated path with the $\pi-\pi$-stacked one in a single system. Interestingly, a theoretical study on charge transport through long and extended helicenes predicted their semiconducting or metallic behaviour. ${ }^{[16]}$ One of the synthetic approaches to the long corkscrew-shaped $\pi$-electron systems might be self-assembly of helicenes at interfaces, provided that control of the $\pi-\pi$ interaction between individual molecules, their orientation to the substrate plane and the cross-section of the formed aggregate can be controlled. We reasoned that [7]helicene-2-carboxylic acid (10) (Figure 1) on calcite could fulfil these requirements. In addition to $\pi-\pi$ stacking, hydrogen bonding between the carboxy groups themselves and/or between them and the substrate might favour the formation of well-defined, wirelike structures. It is worth noting that a well-defined directing effect of hydrogen bonding in the self-assembly of $\pi$ electron systems on surfaces has already been described: Functionalised tetrathiafulvalene (TTF) molecules preferred either $\pi-\pi$ interaction with the highly ordered pyrolytic graphite (HOPG) surface (lying flat upon it) ${ }^{[17]}$ or interaction amongst themselves (being ordered orthogonally to the surface because of hydrogen bonds between the amide moieties).${ }^{[18]}$ Herein, we report the synthesis of racemic [7]helicene-2-carboxylic acid (10) and its resolution into enantiomers. The study of the self-assembly of $\mathbf{1 0}$ on an insulating substrate such as calcite (10-14) by noncontact atomic force microscopy (NC-AFM) is ongoing, and a part of that study has recently been published. ${ }^{[19]}$

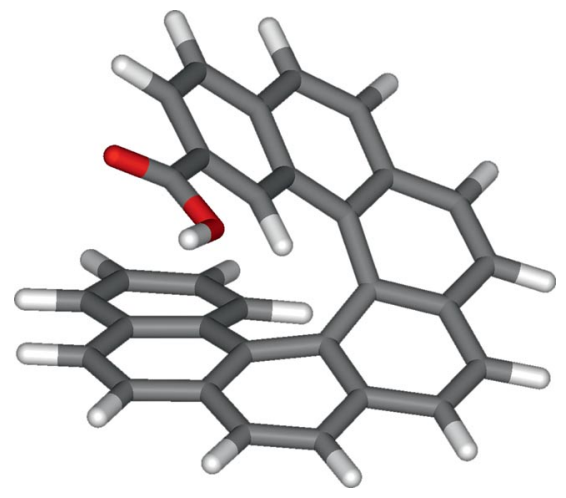

Figure 1. Molecular model of $(P)$-[7]helicene-2-carboxylic acid (10).

\section{Results and Discussion}

All of the known syntheses of [7]helicenecarboxylic acids or their derivatives (2-, 3- or 4-carboxylic acid ${ }^{[20]}$ and 2,17${ }^{[21]}$ or 3,4-dicarboxylic acid ${ }^{[22]}$ ) benefited from the construction of the helical aromatic backbone by the widely used photodehydrocyclisation methodology. ${ }^{[23]}$ However, new synthetic approaches to helicenes have recently emerged ${ }^{[7]}$ and, amongst them, the $[2+2+2]$ cycloisomerisation of aromatic triynes ${ }^{[24]}$ represents a good alternative to classical photochemical synthesis.

Preparation of the previously unknown [7]helicene-2-carboxylic acid (10) started from commercially available 7-methoxy-2-naphthol and 1-bromo-2-(bromomethyl)naphthalene, which were transformed by known procedures into naphthyl iodide $\mathbf{1}^{[25]}$ and naphthylethyne $\mathbf{2}^{[26]}$ (Scheme 1). A Sonogashira coupling between these two building blocks led smoothly to the aromatic triyne $\mathbf{3}$ in good yield, which

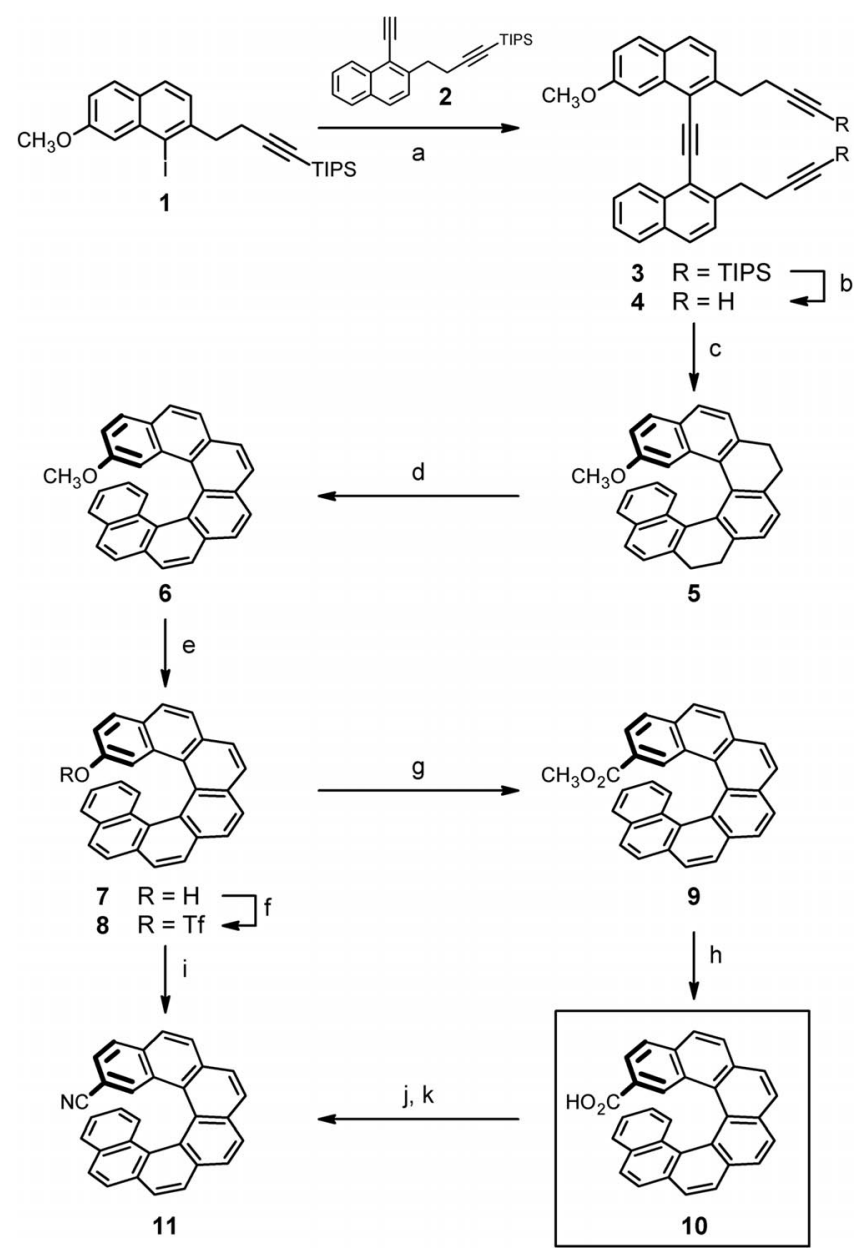

Scheme 1. Synthesis of racemic [7]helicene-2-carboxylic acid (10) and the corresponding nitrile $\mathbf{1 1}$ (only one enantiomer is shown throughout). Reagents and conditions: (a) 2 (1.0 equiv.), $\left[\mathrm{Pd}\left(\mathrm{PPh}_{3}\right)_{4}\right](10 \mathrm{~mol}-\%)$, CuI $(20 \mathrm{~mol}-\%), i \mathrm{Pr}_{2} \mathrm{NH}, 80^{\circ} \mathrm{C}, 1.5 \mathrm{~h}$, $84 \%$; (b) $n \mathrm{Bu}_{4} \mathrm{NF}$ (2.5 equiv.), THF, room temp., $2 \mathrm{~h}, 99 \%$; (c) [CpCo(CO) $)_{2}$ (1.0 equiv.), $\mathrm{PPh}_{3}$ (2.0 equiv.), halogen lamp, decane, $140{ }^{\circ} \mathrm{C}, 2 \mathrm{~h}, 85 \%$; (d) $\mathrm{Ph}_{3} \mathrm{CBF}_{4}$ (2.5 equiv.), 1,2-dichloroethane, $60{ }^{\circ} \mathrm{C}, 1 \mathrm{~h}$, then $80{ }^{\circ} \mathrm{C}, 3 \mathrm{~h}, 90 \%$; (e) EtSNa (20 equiv.), DMF, $130{ }^{\circ} \mathrm{C}, 11 \mathrm{~h}, 82 \%$; (f) $\mathrm{Tf}_{2} \mathrm{O}$ (2.0 equiv.), DMAP (1.2 equiv.), $\mathrm{CH}_{2} \mathrm{Cl}_{2}, 0{ }^{\circ} \mathrm{C}$ to room temp., $3 \mathrm{~h}, 96 \%$; (g) $\mathrm{CO}$ (1 atm), [Pd$(\mathrm{OAc})_{2}$ ] $(20 \mathrm{~mol}-\%)$, dppp $\left(20 \mathrm{~mol}^{-} \%\right), \mathrm{Et}_{3} \mathrm{~N}$ (2.6 equiv.), DMSO/ $\mathrm{MeOH}$ (3:2), $70{ }^{\circ} \mathrm{C}, 12 \mathrm{~h}, 71 \%$; (h) $\mathrm{CH}_{3} \mathrm{ONa}$ (100 equiv.), wet methanol, $80^{\circ} \mathrm{C}, 24 \mathrm{~h}$, then aqueous $\mathrm{HCl}, 99 \%$; (i) TMS-CN (2.0 equiv.), $\left[\mathrm{Pd}(\mathrm{OAc})_{2}\right](20 \mathrm{~mol}-\%)$, dppp (20 mol- $\left.\%\right)$, TMEDA (2.0 equiv.), toluene, $100{ }^{\circ} \mathrm{C}, 4 \mathrm{~h}, 5 \%$; (j) $\mathrm{SOCl}_{2}$ (excess), DMF (cat.), $80^{\circ} \mathrm{C}, 2 \mathrm{~h}$, in a sealed tube, then quenched with aqueous $\mathrm{NH}_{3}$ (excess), $0{ }^{\circ} \mathrm{C}, 64 \%$ of crude carboxamide; (k) $\mathrm{Tf}_{2} \mathrm{O}$ (10.0 equiv.), $\mathrm{Et}_{3} \mathrm{~N}$ (20.0 equiv.), $\mathrm{CH}_{2} \mathrm{Cl}_{2}, 0{ }^{\circ} \mathrm{C}$ to room temp., $2 \mathrm{~h}$, $19 \%$. 
Table 1. Aromatisation of tetrahydroderivative 5 to [7]helicene 6.

\begin{tabular}{cccc}
\hline Entry & Reagents (equiv.) & Conditions & Yield [\%] $]^{\text {[a] }}$ \\
\hline 1 & $\mathrm{MnO}_{2}(30.0)$ & toluene, microwave irradiation, $150-170{ }^{\circ} \mathrm{C}, 3.5 \mathrm{~h}$ & $\mathrm{ca} .5$ \\
2 & $\mathrm{Ph}_{3} \mathrm{COH}(3.8)$ & TFA, reflux, $2 \mathrm{~h}$ & 14 \\
3 & $\mathrm{DDQ}(7.0)$ & toluene, microwave irradiation, $170{ }^{\circ} \mathrm{C}, 4 \mathrm{~h}$ & 54 \\
4 & $\mathrm{Ph}_{3} \mathrm{CBF}_{4}(2.5)$ & 1,2-dichloroethane, $60-80{ }^{\circ} \mathrm{C}, 4 \mathrm{~h}$ & 90 \\
\hline
\end{tabular}

[a] Isolated yield.

underwent quantitatively the desilylation reaction to afford the unprotected triyne 4. Having this key intermediate in hand, it was subjected to intramolecular $[2+2+2]$ cycloisomerisation, mediated by $\mathrm{CpCo}(\mathrm{CO})_{2} / \mathrm{PPh}_{3}$, to obtain the tetrahydro[7]helicene derivative $\mathbf{5}$ in good yield. The cyclisation strategy guaranteed the unambiguous regioselectivity of the ring closure. Therefore, by performing this reaction, the helical backbone was created with the required substituent in the defined position. The subsequent aromatisation step required optimisation to obtain the pure 2-methoxy[7]helicene 6 in a high yield. The first attempt at oxidation of 5 with $\mathrm{MnO}_{2}$ under microwave irradiation failed (Table 1, Entry 1) despite the fact that this method was the only one to work with difficult to oxidise tetrahydroazahelicenes. ${ }^{[27]}$ The use of triphenylmethanol in boiling trifluoroacetic acid or 2,3-dichloro-5,6-dicyano-1,4-benzoquinone (DDQ) under microwave irradiation (Table 1, Entries 2 and 3) led to the desired helicene $\mathbf{6}$, but in low or moderate yield, respectively, accompanied by a series of side products. The best result was obtained by treatment of $\mathbf{5}$ with tritylium tetrafluoroborate at $80^{\circ} \mathrm{C}$ to afford the fully aromatic helicene 6 in high yield (Table 1, Entry 4).

The cleavage of methyl ether $\mathbf{6}$, mediated by sodium ethanethiolate, afforded helicenol 7 in good yield. We had previously found ${ }^{[28]}$ that this method for the demethylation of methoxyhelicenes can be superior to the more commonly used treatment with $\mathrm{BBr}_{3}$. By transforming 7 into the corresponding triflate $\mathbf{8}$ in an almost quantitative yield, a reactive [7]helicene derivative was prepared that allowed the desired functional group manipulation. Indeed, the methoxycarbonylation of $\mathbf{8}$ under $\left[\mathrm{Pd}(\mathrm{OAc})_{2}\right] / \mathrm{dppp}$ catalysis led to the formation of ester 9 in good yield. To complete the synthesis, methyl [7]helicene-2-carboxylate (9) was hydrolysed under basic conditions to the final product, [7]helicene-2carboxylic acid (10), in quantitative yield.

In connection with the scanning tunnelling microscopy (STM) and noncontact atomic force microscopy (NCAFM) study on the dipole-moment-assisted self-assembly of chiral molecules at interfaces, we proposed nitrile $\mathbf{1 1}$ (Scheme 1) as a suitable candidate due to its helical shape, dipole moment (4.73 debye, calculated by DFT/b3lyp/cc$\mathrm{pVTZ}$ ) and rather rigid structure that is free of conformational ambiguity. First, an attempt was made to convert triflate $\mathbf{8}$ directly into nitrile $\mathbf{1 1}$ by Pd-catalysed cyanation. Unfortunately, nitrile $\mathbf{1 1}$ was obtained in only low yields, even under a range of reaction conditions. ${ }^{[29]}$ Thus, we decided to use a more conventional approach to transforming carboxylic acids into the corresponding nitrile through amide dehydration. After treatment of acid $\mathbf{1 0}$ with thionyl chloride, the intermediary acyl chloride was subjected to aminolysis to afford heptahelicene-2-carboxamide in moderate yield. However, final dehydration mediated by triflic anhydride again provided nitrile $\mathbf{1 1}$ in a low yield.

To obtain [7]helicene-2-carboxylic acid (10) in an optically pure form, we considered resolving the helical products by preparative liquid chromatography on a chiral stationary phase (CSP) column. We found that excellent separation of racemic acid $\mathbf{1 0}$ into its enantiomers could be achieved by using a PST-4 CSP (Chirallica) column with heptane/2-propanol (95:5) as mobile phase. Thus, by repeated loading of $0.2 \mathrm{mg}$ samples of $\mathbf{1 0}$ onto the analytical column, both optically pure enantiomers were obtained (Figure 2).

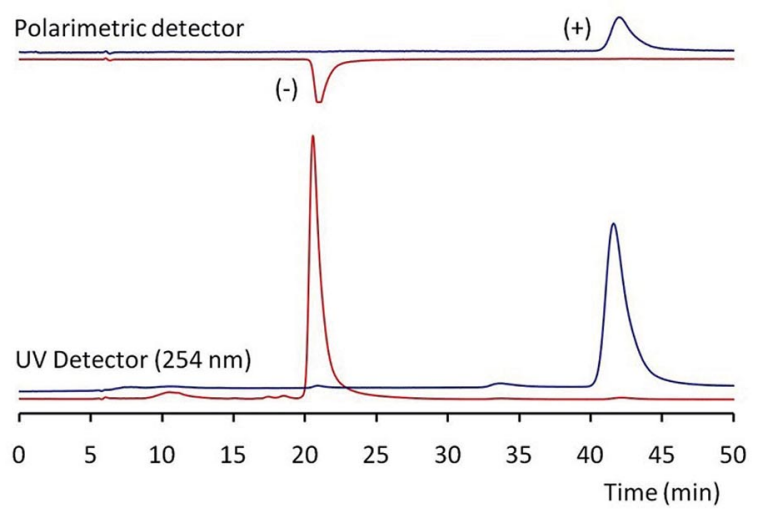

Figure 2. HPLC resolution of racemic [7]helicene-2-carboxylic acid (10) into the (-)-enantiomer $\left(t_{\mathrm{R}}=20.5 \mathrm{~min}\right)$ and the $(+)$-enantiomer $\left(t_{\mathrm{R}}=41.6 \mathrm{~min}\right)$. Conditions: Chirallica PST- 4 column $(5 \mu \mathrm{m}$, $250 \times 4.6 \mathrm{~mm}$ ); heptane/2-propanol (95:5); flow rate: $0.6 \mathrm{~mL} / \mathrm{min}$; repetitive $0.2 \mathrm{mg}$ injections (the superposition of chromatograms of pure enantiomers shown).

With the separated enantiomers (-)-10 and (+)-10 in hand, we could assign their helicity by correlating their $C D$ spectra with that of the structurally closest related $(+)-(P)$ [7] helicene (Figure 3), ${ }^{[30]}$ the helicity of which was unambiguously determined ${ }^{[31]}$ and its $C D$ spectrum published. ${ }^{[32]}$ Comparing the $\mathrm{CD}$ spectra of the dextrorotatory enantiomer of [7]helicene-2-carboxylic acid (+)-10 and $(+)-(P)$ [7]helicene, we found excellent agreement with respect to both the dichroism and intensities of all bands. Accordingly, we could clearly assign $(P)$ helicity to $(+)-\mathbf{1 0}$ and $(M)$ helicity to (-)-10.

We proposed that the carboxy group attached to the [7]helicene scaffold can possibly assist in the self-assembly 


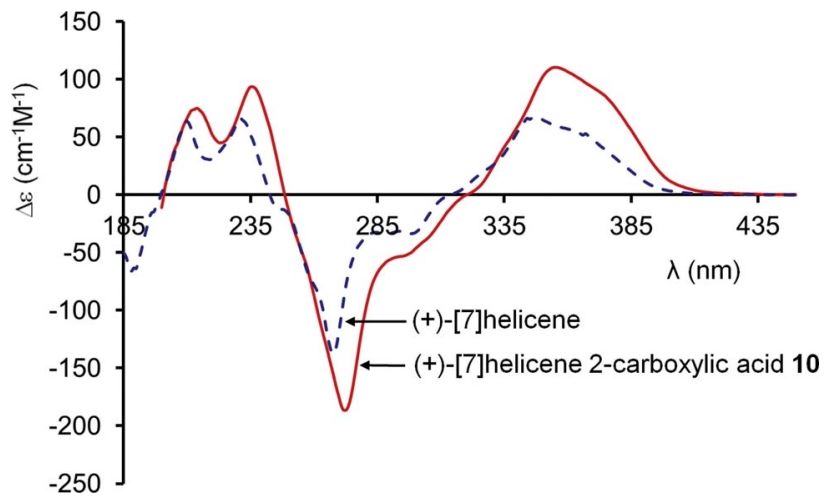

Figure 3. CD spectra of $(+)-(P)-[7]$ helicene-2-carboxylic acid (10) (red solid line $)$ in acetonitrile $\left(5.6 \times 10^{-5} \mathrm{M}\right)$ and $(+)-(P)-[7]$ helicene (blue dashed line) in acetonitrile as a reference. ${ }^{[32]}$

of $\mathbf{1 0}$ on a calcite (10-14) substrate. Not only might intermolecular carboxylic acid dimers ${ }^{[33]}$ be formed, but interactions between the carboxylic groups and the mineral surface might also occur (either through hydrogen bonding between the carboxylic acids and carbonate anions or through Coulombic attraction between the deprotonated carboxylic groups and $\mathrm{Ca}^{2+}$ ions). ${ }^{[34]}$ To verify this assumption, we deposited racemic [7]helicene-2-carboxylic acid (10) onto a calcite (10-14) surface by thermal evaporation under ultrahigh vacuum. Using non-contact atomic force microscopy (NC-AFM), we observed the intriguing self-assembly of $\mathbf{1 0}$ into nanowire-like aggregates (Figure 4) ${ }^{[19]}$

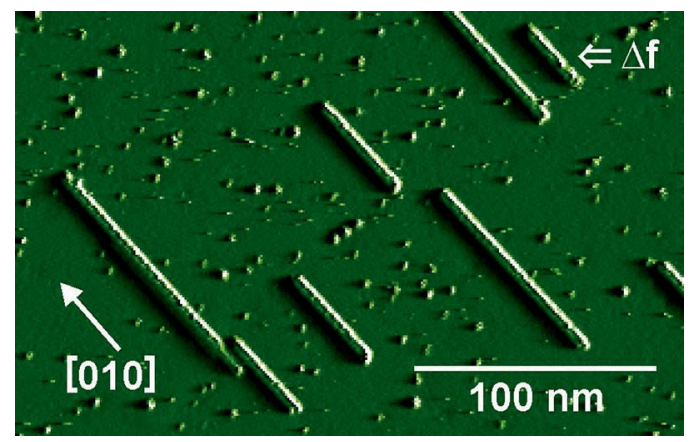

Figure 4. Racemic [7]helicene-2-carboxylic acid (10) deposited on calcite (10-14), imaged by NC-AFM.

The supramolecular self-assembled nanostructures featured an unidirectional pattern that was well aligned along the [010] crystallographic direction of the calcite (10-14) cleavage plane. These wire-like structures were of well-defined width, their lengths exceeded $100 \mathrm{~nm}$ and the assemblies on a truly insulating substrate were stable at room temperature. Based on a detailed analysis of the NC-AFM images and on the results of DFT calculations, ${ }^{[19]}$ we could describe the nanowire structures as columnar stacks of dimers of [7]helicene-2-carboxylic acid (10) on the surface with all the individual helicene molecules in the upright position relative to the surface.

\section{Conclusions}

A straightforward synthesis of [7]helicene-2-carboxylic acid (10) that employed suitably functionalised naphthalene building blocks has been developed. The key operation in building the helical skeleton was a $\mathrm{Co}^{\mathrm{I}}$-mediated $[2+2+2]$ cycloisomerisation of an aromatic triyne. The carboxylic moiety was introduced by $\mathrm{Pd}^{\mathrm{II}}$-catalysed methoxycarbonylation reaction with the corresponding helicene triflate. The racemic [7]helicene-2-carboxylic acid (10) was resolved into enantiomers by semipreparative HPLC on a chiral column, and their helicity was assigned by CD spectra correlation. Racemic [7]helicene-2-carboxylic acid (10) was deposited on calcite (10-14) to undergo self-assembly into nanowire-like aggregates, as demonstrated by NC-AFM studies. ${ }^{[19]}$ This study showed that selecting suitably functionalised molecules enabled the self-assembly of molecular wire-like structures even on insulating surfaces, where high molecular mobility has so far hampered the self-assembly of tailor-made molecular structures. Clearly, the formation of these nanowire-like aggregates was governed by a balanced interplay of the $\pi-\pi$ interactions between large aromatic systems and hydrogen bonding between the carboxylic groups themselves or the electrostatic interaction between the carboxylate moieties and the calcite substrate. Further studies on the self-assembly of enantiopure $\mathbf{1 0}$ are underway.

\section{Experimental Section}

General: The ${ }^{1} \mathrm{H}$ NMR spectra were measured at 400.13, 499.88, or $600.13 \mathrm{MHz}$, the ${ }^{13} \mathrm{C} \mathrm{NMR}$ spectra at $100.61,125.71$, or $150.90 \mathrm{MHz}$ in $\mathrm{CDCl}_{3}$ with TMS as an internal standard. Chemical shifts $(\delta)$ are given in ppm, the coupling constants $J$ are given in $\mathrm{Hz}$. $\mathrm{HMBC}$ experiments were set up for $J_{\mathrm{C}-\mathrm{H}}=5 \mathrm{~Hz}$. For the correct assignment of both the ${ }^{1} \mathrm{H}$ and ${ }^{13} \mathrm{C}$ NMR spectra of key compounds, COSY, HMQC and HMBC experiments were performed. The IR spectra were measured in $\mathrm{CHCl}_{3}$. The EI mass spectra were determined at an ionising voltage of $70 \mathrm{eV}$, the $\mathrm{m} / \mathrm{z}$ values are given along with their relative intensities (\%). The standard $70 \mathrm{eV}$ spectra were recorded in the positive ion mode. The TOF EI mass spectra were measured with an orthogonal-acceleration time-of-flight mass spectrometer from GCT Premier (Waters). The sample was dissolved in chloroform, loaded into a quartz cup of the direct probe and inserted into the ion source. The source temperature was $220^{\circ} \mathrm{C}$. For exact mass measurement, the spectra were internally calibrated by using perfluorotri- $n$-butylamine (Heptacosa). The ESI and APCI mass spectra were recorded with a ZQ micromass mass spectrometer (Waters) equipped with an ESCi multi-mode ion source and controlled by MassLynx software. Methanol was used as solvent. Accurate mass measurements were obtained with EI or TOF EI MS. Optical rotation was measured with an Autopol IV (Rudolph Research Analytical) instrument. CD spectra were acquired with a J-815 CD spectrometer (Jasco Analytical Instruments, Inc.) in acetonitrile by using a $10 \mathrm{~mm}$ quartz sample cell. Commercially available catalysts and reagent-grade materials were used as received. Decane was degassed by three freeze/pump/thaw cycles before use; 1,2-dichloroethane, triethylamine and diisopropylamine were distilled from calcium hydride under argon; THF was freshly distilled from sodium/benzophenone under nitrogen; 
HPLC-grade methanol, DMF and DMSO were degassed by three freeze/pump/thaw cycles before use. Toluene was freshly distilled from sodium. TLC was performed on silica gel $60 \mathrm{~F}_{254}$ coated aluminium sheets (Merck), and spots were detected by dipping of the sheets into a solution of $\mathrm{Ce}\left(\mathrm{SO}_{4}\right)_{2} \cdot 4 \mathrm{H}_{2} \mathrm{O}(1 \%)$ and $\mathrm{H}_{3} \mathrm{P}\left(\mathrm{Mo}_{3} \mathrm{O}_{10}\right)_{4}$ $(2 \%)$ in sulfuric acid $(10 \%)$. Flash chromatography was performed on silica gel $60\left(0.040-0.063 \mathrm{~mm}\right.$, Fluka) or with Biotage KP-Sil ${ }^{\circledR}$ silica cartridges $(0.040-0.063 \mathrm{~mm})$ with an $\mathrm{Sp} 1$ or Isolera One HPFC system (Biotage, Inc.).

1-\{2-[4-(Triisopropylsilyl)but-3-ynyl]-1-naphthyl\}-2-\{2-[4-(triisopropylsilyl)but-3-ynyl]-7-methoxy-1-naphthyl\}ethyne (3): A Schlenk flask was charged with $\mathbf{1}^{[25]}(2.08 \mathrm{~g}, 4.23 \mathrm{mmol})$, [Pd( $\left.\left(\mathrm{PPh}_{3}\right)_{4}\right]$ (204 mg, $0.177 \mathrm{mmol}, 10 \mathrm{~mol}-\%)$ and $\mathrm{CuI}(70.0 \mathrm{mg}, 0.368 \mathrm{mmol}$, $20 \mathrm{~mol}-\%)$, flushed with argon, and diisopropylamine $(50 \mathrm{~mL})$ was transferred into the vessel. Then $2^{[26]}$ (1.64 g, $4.23 \mathrm{mmol}, 1.0$ equiv.) dissolved in the same solvent $(10 \mathrm{~mL})$ was added at room temp., and the mixture was stirred at $80{ }^{\circ} \mathrm{C}$ for $1.5 \mathrm{~h}$. The precipitate was filtered off, and the filtrate was concentrated in vacuo. The residue was purified by flash chromatography on silica gel (hexanes/diethyl ether, 100:0 to 90:10) to afford $3(2.57 \mathrm{~g}, 84 \%)$ as an amorphous solid. ${ }^{1} \mathrm{H}$ NMR $\left(500 \mathrm{MHz}, \mathrm{CDCl}_{3}\right): \delta=0.96-1.03(\mathrm{~m}, 42 \mathrm{H}), 2.81$ $(\mathrm{t}, J=7.5 \mathrm{~Hz}, 2 \mathrm{H}), 2.82(\mathrm{t}, J=7.3 \mathrm{~Hz}, 2 \mathrm{H}), 3.40(\mathrm{t}, J=7.5 \mathrm{~Hz}$, $2 \mathrm{H}), 3.43(\mathrm{t}, J=7.3 \mathrm{~Hz}, 2 \mathrm{H}), 4.01(\mathrm{~s}, 3 \mathrm{H}), 7.17(\mathrm{dd}, J=8.9$, $2.6 \mathrm{~Hz}, 1 \mathrm{H}), 7.41(\mathrm{~d}, J=8.3 \mathrm{~Hz}, 1 \mathrm{H}), 7.51(\mathrm{ddd}, J=8.0,6.8$, $1.3 \mathrm{~Hz}, 1 \mathrm{H}), 7.56(\mathrm{~d}, J=8.5 \mathrm{~Hz}, 1 \mathrm{H}), 7.57$ (ddd, $J=8.4,6.8$, $1.4 \mathrm{~Hz}, 1 \mathrm{H}), 7.73(\mathrm{dt}, J=8.3,0.6,0.6 \mathrm{~Hz}, 1 \mathrm{H}), 7.76(\mathrm{~d}, J=$ $8.9 \mathrm{~Hz}, 1 \mathrm{H}), 7.80(\mathrm{dt}, J=8.5,0.6,0.6 \mathrm{~Hz}, 1 \mathrm{H}), 7.87$ (ddt, $J=8.0$, $1.4,0.6,0.6 \mathrm{~Hz}, 1 \mathrm{H}), 7.98(\mathrm{dt}, J=2.6,0.7,0.7 \mathrm{~Hz}, 1 \mathrm{H}), 8.71$ (ddt, $J=8.4,1.3,0.8,0.8 \mathrm{~Hz}, 1 \mathrm{H}) \mathrm{ppm} .{ }^{13} \mathrm{C} \mathrm{NMR}\left(126 \mathrm{MHz}, \mathrm{CDCl}_{3}\right)$ : $\delta=11.26(\mathrm{~d}), 11.28(\mathrm{~d}), 18.55(\mathrm{q}), 18.58(\mathrm{q}), 21.48(\mathrm{t}), 21.56(\mathrm{t})$, $34.87(\mathrm{t}), 35.08$ (t), 55.43 (q), 81.32 (s), 81.54 (s), 94.99 (s), 95.54 (s), 104.39 (d), 107.66 (s), 107.83 (s), 118.37 (s), 118.80 (d), 119.74 (s), 125.42 (d), 125.78 (d), 126.11 (d), 126.73 (d), 127.55 (s), 127.77 (d), 128.21 (d), 128.29 (d), 128.32 (d), 129.76 (d), 132.15 (s), 133.67 (s), 135.20 (s), 141.42 (s), 142.08 (s), 158.81 (s) ppm. IR $\left(\mathrm{CHCl}_{3}\right)$ : $\tilde{v}=3058(\mathrm{w}), 3008(\mathrm{w}), 2891(\mathrm{~s}), 2865(\mathrm{vs}), 2170(\mathrm{~m}), 1623(\mathrm{~s}), 1594$ (w), $1570(\mathrm{w}), 1510(\mathrm{~m}), 1462$ (s), $1423(\mathrm{w}), 1383(\mathrm{~m}), 1366(\mathrm{w})$, 1317 (w), 1266 (w), 1176 (w), 1073 (w), 1036 (m), 1027 (w), 996 (m), 883 (s), $839(\mathrm{~m}), 816(\mathrm{~m}), 678(\mathrm{~s}), 660$ (s), $625(\mathrm{~m}) \mathrm{cm}^{-1}$. MS (EI): $m / z(\%)=724(11)[\mathrm{M}]^{+*}, 681$ (7), 157 (37), 115 (100), 87 (64), 73 (75), 59 (85). HRMS (EI): calcd. for $\mathrm{C}_{49} \mathrm{H}_{64} \mathrm{OSi}_{2}$ 724.4496; found 724.4497 .

1-[2-(But-3-ynyl)-1-naphthyl]-2-[2-(but-3-ynyl)-7-methoxy-1-naphthyllethyne (4): In a Schlenk flask, tetrabutylammonium fluoride trihydrate (498 mg, $1.58 \mathrm{mmol}, 2.5$ equiv.) was briefly dried in vacuo at room temp. and then dissolved in THF $(10 \mathrm{~mL})$ under argon. The silylated triyne 3 (458 mg, $0.632 \mathrm{mmol})$ in THF $(10 \mathrm{~mL})$ was added in one portion at room temp. After $2 \mathrm{~h}$ of stirring, the reaction mixture was rapidly transferred onto a silica gel column and purified (hexanes/diethyl ether, 100:0 to 95:5). The crude product was dried in vacuo $(<50 \mathrm{~Pa})$ at room temp. for $6 \mathrm{~h}$ to give triyne $4(260 \mathrm{mg}, 99 \%)$ as a waxy solid. ${ }^{1} \mathrm{H}$ NMR $\left(500 \mathrm{MHz}, \mathrm{CDCl}_{3}\right): \delta$ $=2.02(\mathrm{t}, J=2.7 \mathrm{~Hz}, 1 \mathrm{H}), 2.74(\mathrm{dt}, J=7.8,7.8,2.4 \mathrm{~Hz}, 2 \mathrm{H})$, $2.75(\mathrm{dt}, J=7.5,7.5,2.7 \mathrm{~Hz}, 2 \mathrm{H}), 3.42(\mathrm{t}, J=7.8 \mathrm{~Hz}, 2 \mathrm{H}), 3.45$ (t, $J=7.5 \mathrm{~Hz}, 2 \mathrm{H}), 4.00(\mathrm{~s}, 3 \mathrm{H}), 7.19(\mathrm{dd}, J=8.9,2.6 \mathrm{~Hz}, 1 \mathrm{H})$, 7.36 (d, $J=8.3 \mathrm{~Hz}, 1 \mathrm{H}), 7.52$ (ddd, $J=8.1,6.8,1.3 \mathrm{~Hz}, 1 \mathrm{H}), 7.52$ $(\mathrm{d}, J=8.4 \mathrm{~Hz}, 1 \mathrm{H}), 7.59(\mathrm{ddd}, J=8.3,6.8,1.4 \mathrm{~Hz}, 1 \mathrm{H}), 7.77(\mathrm{dt}$, $J=8.3,0.6,0.6 \mathrm{~Hz}, 1 \mathrm{H}), 7.77(\mathrm{~d}, J=8.9 \mathrm{~Hz}, 1 \mathrm{H}), 7.84(\mathrm{dt}, J=$ 8.4, 0.6, $0.6 \mathrm{~Hz}, 1 \mathrm{H}), 7.88$ (ddt, $J=8.1,1.4,0.7,0.7 \mathrm{~Hz}, 1 \mathrm{H}), 7.96$ $(\mathrm{dt}, J=2.6,0.6,0.6 \mathrm{~Hz}, 1 \mathrm{H}), 8.69$ (ddt, $J=8.3,1.3,0.8,0.8 \mathrm{~Hz}$, $1 \mathrm{H}) \mathrm{ppm} .{ }^{13} \mathrm{C} \mathrm{NMR}\left(126 \mathrm{MHz}, \mathrm{CDCl}_{3}\right): \delta=19.95(\mathrm{t}), 20.09(\mathrm{t})$, $34.50(\mathrm{t}), 34.75(\mathrm{t}), 55.50(\mathrm{q}), 69.23$ (d), 69.43 (d), 83.54 (s), 83.67 (s), 94.92 (s), 95.46 (s), 104.46 (d), 118.41 (s), 118.92 (d), 119.79 (s),
125.01 (d), 125.97 (d), 126.16 (d), 126.95 (d), 127.34 (d), 127.56 (s), 128.36 (d), 128.46 (d), 128.55 (d), 129.84 (d), 132.15 (s), 133.70 (s), 135.21 (s), 141.03 (s), 141.80 (s), 158.94 (s) ppm. IR $\left(\mathrm{CHCl}_{3}\right)$ : $\tilde{\mathrm{v}}=$ 3308 (vs), 3059 (w), 2840 (w), 2832 (w), 2192 (vw), 2118 (w), 1623 (vs), 1595 (w), 1570 (w), 1511 (s), 1430 (m), 1423 (m), 1318 (w), $1257(\mathrm{~m}), 1177$ (m), $1028(\mathrm{~m}), 867$ (w), 841 (s), 640 (s), $526(\mathrm{w})$ $\mathrm{cm}^{-1}$. MS (EI): $m / z(\%)=412(100)[\mathrm{M}]^{+\cdot}, 341(20), 326(20), 313$ (19), 289 (23), 171 (23), 163 (22), 145 (24). HRMS (EI): calcd. for $\mathrm{C}_{31} \mathrm{H}_{24} \mathrm{O}$ 412.1827; found 412.1847 .

2-Methoxy-7,8,11,12-tetrahydro[7]helicene (5): In a three-necked Schlenk flask, triyne $4(20 \mathrm{mg}, 0.049 \mathrm{mmol})$ and $\mathrm{PPh}_{3}(26 \mathrm{mg}$, $0.098 \mathrm{mmol}, 2.0$ equiv.) were flushed with argon and suspended in decane $(8 \mathrm{~mL})$. The reaction mixture was heated to $90{ }^{\circ} \mathrm{C}$, until a clear solution was formed. Then $\left[\mathrm{CpCo}(\mathrm{CO})_{2}\right] \quad(6.5 \mu \mathrm{L}$, $0.049 \mathrm{mmol}, 1.0$ equiv. $)$ in decane $(2 \mathrm{~mL})$ was added in one portion. The mixture was heated to $140{ }^{\circ} \mathrm{C}$ under simultaneous irradiation with a $500 \mathrm{~W}$ halogen lamp for $2 \mathrm{~h}$. After cooling to room temp., the crude reaction mixture was diluted with a small amount of dichloromethane and subjected directly to flash chromatography on silica gel (hexanes/diethyl ether, 100:0 to 95:5) to afford the tetrahydrohelicene derivative $\mathbf{5}(17 \mathrm{mg}, 85 \%)$ as a yellow amorphous solid. ${ }^{1} \mathrm{H}$ NMR $\left(500 \mathrm{MHz}, \mathrm{CDCl}_{3}\right): \delta=2.71-2.83(\mathrm{~m}, 2 \mathrm{H})$, 2.92-3.10 (m, $6 \mathrm{H}), 3.50(\mathrm{~s}, 3 \mathrm{H}), 6.26(\mathrm{~d}, J=2.5 \mathrm{~Hz}, 1 \mathrm{H}), 6.52$ (dd, $J=8.8,2.5 \mathrm{~Hz}, 1 \mathrm{H}), 6.52(\mathrm{ddd}, J=8.7,6.7,1.4 \mathrm{~Hz}, 1 \mathrm{H})$, 6.83 (ddd, $J=8.1,6.7,1.1 \mathrm{~Hz}, 1 \mathrm{H}$ ), 6.92 (ddt, $J=8.7,1.1,0.8$, $0.8 \mathrm{~Hz}, 1 \mathrm{H}), 7.12(\mathrm{dt}, J=8.8,0.5,0.5 \mathrm{~Hz}, 1 \mathrm{H}), 7.23(\mathrm{dd}, J=8.0$, $0.7 \mathrm{~Hz}, 1 \mathrm{H}), 7.24$ (ddt, $J=8.1,1.4,0.6,0.6 \mathrm{~Hz}, 1 \mathrm{H}), 7.27$ (dd, $J$ $=8.0,0.7 \mathrm{~Hz}, 1 \mathrm{H}), 7.33(\mathrm{dt}, J=8.2,0.6,0.6 \mathrm{~Hz}, 1 \mathrm{H}), 7.34(\mathrm{dd}$, $J=7.3,0.7 \mathrm{~Hz}, 1 \mathrm{H}), 7.36(\mathrm{dd}, J=7.3,0.7 \mathrm{~Hz}, 1 \mathrm{H}), 7.39(\mathrm{~d}, J=$ $8.2 \mathrm{~Hz}, 1 \mathrm{H}) \mathrm{ppm} .{ }^{13} \mathrm{C} \mathrm{NMR}\left(126 \mathrm{MHz}, \mathrm{CDCl}_{3}\right): \delta=30.52(\mathrm{t})$, $30.59(\mathrm{t}), 31.30(\mathrm{t}), 31.40(\mathrm{t}), 54.26(\mathrm{q}), 102.41(\mathrm{~d}), 116.63(\mathrm{~d})$, 123.64 (d), 123.71 (d), 123.73 (d), 123.94 (d), 125.66 (d), 125.83 (d), 125.86 (d), 126.56 (d), 127.06 (d), 127.48 (d), 127.93 (s), 128.33 (d), 128.85 (s), 130.46 (s), 131.83 (s), 132.16 (s), 132.38 (s), 132.87 (s), 133.10 (s), 137.00 (s), 138.48 (s), 139.49 (s), 139.95 (s), 156.61 (s) ppm. IR $\left(\mathrm{CHCl}_{3}\right): \tilde{v}=3052(\mathrm{~m}), 2942(\mathrm{~s}), 2897(\mathrm{~m}), 2834(\mathrm{~m}), 1623$ (s), 1599 (m), 1579 (w), 1566 (m), 1515 (s), 1491 (w), 1466 (s), 1437 (m), 1410 (w), 1308 (w), 1260 (s), 1243 (s), 1174 (s), 1032 (m), 914 (w), $856(\mathrm{~m}), 837(\mathrm{~s}) \mathrm{cm}^{-1}$. MS (EI): $m / z(\%)=412(8)[\mathrm{M}]^{+*}, 316$ (14), 288 (38), 278 (35), 243 (95), 211 (53), 183 (25), 165 (38), 159 (76), 149 (89), 121 (36), 105 (100), 77 (60), 57 (54), 43 (50). HRMS (EI): calcd. for $\mathrm{C}_{31} \mathrm{H}_{24} \mathrm{O} 412.1827$; found 412.1819 .

2-Methoxy[7]helicene (6): A stirred solution of tetrahydrohelicene 5 (180 mg, $0.436 \mathrm{mmol})$ and tritylium tetrafluoroborate $(360 \mathrm{mg}$, $1.09 \mathrm{mmol}, 2.5$ equiv.) in 1,2-dichloroethane $(5 \mathrm{~mL})$ was heated to $60{ }^{\circ} \mathrm{C}$ for $1 \mathrm{~h}$ and then to $80^{\circ} \mathrm{C}$ for $3 \mathrm{~h}$ under argon. After cooling to room temp., the reaction was quenched with triethylamine $(0.5 \mathrm{~mL})$. The crude reaction mixture was filtered through a pad of silica gel in toluene and precipitated with heptane to give helicene $6(41 \mathrm{mg})$ as a yellow amorphous solid. Flash chromatography of the mother liquor (hexanes/diethyl ether, 100:0 to 80:20) afforded further pure $6(120 \mathrm{mg}$ ) as a yellow oil (combined yield $90 \%) .{ }^{1} \mathrm{H}$ NMR (400 MHz, $\mathrm{CDCl}_{3}$ ): $\delta=3.11$ (s, $3 \mathrm{H}$ ), 6.40 (ddd, $J=8.4,6.9$, $1.4 \mathrm{~Hz}, 1 \mathrm{H}), 6.57-6.60$ (m, $2 \mathrm{H}), 6.92$ (ddd, $J=8.8,6.9,1.2 \mathrm{~Hz}, 1$ H), $7.10(\mathrm{ddt}, J=8.5,1.2,0.7,0.7 \mathrm{~Hz}, 1 \mathrm{H}), 7.22(\mathrm{~d}, J=9.5 \mathrm{~Hz}$, $1 \mathrm{H}), 7.35-7.37(\mathrm{~m}, 1 \mathrm{H}), 7.46(\mathrm{~d}, J=8.4 \mathrm{~Hz}, 1 \mathrm{H}), 7.59$ (d, $J=$ $8.5 \mathrm{~Hz}, 1 \mathrm{H}), 7.65(\mathrm{~d}, J=8.4 \mathrm{~Hz}, 1 \mathrm{H}), 7.76(\mathrm{~d}, J=8.5 \mathrm{~Hz}, 1 \mathrm{H})$, $7.90-7.94$ (m, $2 \mathrm{H}), 7.99$ (d, $J=8.2 \mathrm{~Hz}, 1 \mathrm{H}), 8.03$ (d, $J=8.2 \mathrm{~Hz}$, $1 \mathrm{H}), 8.05$ (br. s, $2 \mathrm{H}$ ) ppm. $\left.{ }^{13} \mathrm{C} \mathrm{NMR} \mathrm{(101} \mathrm{MHz,} \mathrm{CDCl}_{3}\right): \delta=$ 53.85 (q), 104.44 (d), 116.95 (d), 123.44 (d), 123.45 (d), 124.38 (d), 124.97 (s), 125.02 (d), 125.09 (s), 125.35 (d), 126.59 (d), 126.63 (d), 126.71 (d), 126.80 (s), 126.83 (d), 126.89 (d), 127.04 (d), 127.20 (d), 127.60 (s), 127.66 (d), 127.70 (d), 128.17 (d), 128.57 (s), 129.31 (s), 
130.74 (s), 130.84 (s), 131.24 (s), 131.75 (s), 131.85 (s), 131.93 (s), 156.45 (s) ppm. IR $\left(\mathrm{CHCl}_{3}\right): \tilde{v}=3052(\mathrm{~m}), 2835(\mathrm{w}), 1619(\mathrm{~m})$, 1609 (m), 1578 (w), 1552 (vw), 1520 (w), 1504 (m), 1473 (w), 1463 (w), 1448 (w), 1427 (m), 1034 (m), 863 (m), 850 (s), 841 (vs) cm c $^{-1}$. TOF MS (EI): $m / z(\%)=408(100)\left[\mathrm{M}^{+*}, 393(7), 375(18), 363\right.$ (18), 350 (10), 337 (10), 300 (5), 181 (5). HRMS (EI): calcd. for $\mathrm{C}_{31} \mathrm{H}_{20} \mathrm{O}$ 408.1514; found 408.1511.

2-Hydroxy[7]helicene (7): In a Schlenk flask, sodium hydride (95\%, $118 \mathrm{mg}, 4.90 \mathrm{mmol}, 20$ equiv.) was suspended in DMF (5 mL) under argon and cooled to $0{ }^{\circ} \mathrm{C}$. EtSH $(362 \mu \mathrm{L}, 4.90 \mathrm{mmol}, 20$ equiv. $)$ was then added dropwise, and the mixture was stirred at room temp. until a clear solution was formed. A solution of 2-methoxy[7]helicene (6) (100 mg, $0.245 \mathrm{mmol})$ in DMF (5 mL) was added, and the resulting solution was stirred at $130^{\circ} \mathrm{C}$ for $11 \mathrm{~h}$. After cooling to room temp., the crude reaction mixture was poured into saturated aqueous $\mathrm{NH}_{4} \mathrm{Cl}(50 \mathrm{~mL})$ and extracted with diethyl ether $(3 \times 30 \mathrm{~mL})$. The combined organic portions were washed with brine $(30 \mathrm{~mL})$, dried with anhydrous $\mathrm{Na}_{2} \mathrm{SO}_{4}$, and the solvents evaporated in vacuo to dryness. Flash chromatography on silica gel (heptane/ethyl acetate, 90:10) afforded the pure hydroxy[7]helicene (7) $(80 \mathrm{mg}, 82 \%)$ as a yellow amorphous solid. ${ }^{1} \mathrm{H}$ NMR $\left(400 \mathrm{MHz}, \mathrm{CDCl}_{3}\right): \delta=3.99$ (br. s, $1 \mathrm{H}$ ), 6.41 (ddd, $J=8.4,6.9$, $1.4 \mathrm{~Hz}, 1 \mathrm{H}), 6.48(\mathrm{~d}, J=2.5 \mathrm{~Hz}, 1 \mathrm{H}), 6.57(\mathrm{dd}, J=8.6,2.5 \mathrm{~Hz}$, $1 \mathrm{H}), 6.93(\mathrm{ddd}, J=8.0,6.9,1.1 \mathrm{~Hz}, 1 \mathrm{H}), 7.13(\mathrm{~d}, J=8.6 \mathrm{~Hz}, 1$ H), $7.22(\mathrm{~d}, J=8.6 \mathrm{~Hz}, 1 \mathrm{H}), 7.38(\mathrm{~d}, J=7.9 \mathrm{~Hz}, 1 \mathrm{H}), 7.44(\mathrm{~d}, J$ $=8.4 \mathrm{~Hz}, 1 \mathrm{H}), 7.63(\mathrm{~d}, J=8.5 \mathrm{~Hz}, 2 \mathrm{H}), 7.77(\mathrm{~d}, J=8.5 \mathrm{~Hz}, 1$ $\mathrm{H}), 7.90-8.03(\mathrm{~m}, 6 \mathrm{H}) \mathrm{ppm} .{ }^{13} \mathrm{C} \mathrm{NMR}\left(101 \mathrm{MHz}, \mathrm{CDCl}_{3}\right): \delta=$ 109.06 (d), 115.58 (d), 123.42 (d), 123.61 (d), 124.39 (d), 124.61 (s), $125.10(3 \times \mathrm{d}), 125.20$ (s), $126.52(\mathrm{~d}), 126.60(\mathrm{~d}), 126.93(3 \times \mathrm{d})$, 126.97 (s), 126.99 (d), 127.15 (s), 127.18 (d), 127.61 (d), 127.67 (d), 128.57 (d), 128.75 (s), 129.29 (s), 130.46 (s), 130.71 (s), 131.34 (s), 131.73 (s), 131.82 (s), 131.97 (s), 152.43 (s) ppm. IR $\left(\mathrm{CHCl}_{3}\right): \tilde{\mathrm{v}}=$ 3592 (w), 3398 (vw), 3052 (w), 1625 (w), 1607 (m), 1579 (vw), 1556 (vw), $1529(\mathrm{w}), 1518(\mathrm{w}), 1505(\mathrm{w}), 1472(\mathrm{w}), 1421(\mathrm{w}), 866(\mathrm{w})$, 854 (m), 843 (vs) $\mathrm{cm}^{-1}$. TOF MS (EI): $\mathrm{m} / z(\%)=394(100)[\mathrm{M}]^{+*}$, 374 (12), 361 (12), 350 (12), 337 (18), 324 (5), 300 (10), 223 (5), 205 (5), 187 (7), 181 (5), 149 (62), 104 (5). HRMS (EI): calcd. for $\mathrm{C}_{30} \mathrm{H}_{18} \mathrm{O}$ 394.1358; found 394.1355.

[7]Helicen-2-yl Triflate (8): Triflic anhydride $(81 \mu \mathrm{L}, 0.48 \mathrm{mmol}$, 2.0 equiv.) was added dropwise to a solution of 2-hydroxy[7]helicene (7) (94 mg, $0.24 \mathrm{mmol}$ ) and 4-(dimethylamino)pyridine (73 mg, $0.29 \mathrm{mmol}, 1.2$ equiv.) in dichloromethane $(5 \mathrm{~mL})$ at $0{ }^{\circ} \mathrm{C}$ under argon. The solution was slowly warmed to room temp. over $3 \mathrm{~h}$. The resulting solution was filtered through a pad of silica gel (dichloromethane), and the solvents were evaporated in vacuo to dryness to give helicene triflate $8(120 \mathrm{mg}, 96 \%)$ as a yellow oil. ${ }^{1} \mathrm{H}$ NMR $\left(400 \mathrm{MHz}, \mathrm{CDCl}_{3}\right): \delta=6.38$ (ddd, $J=8.4,6.9,1.3 \mathrm{~Hz}, 1$ $\mathrm{H}), 6.82(\mathrm{dd}, J=8.8,2.5 \mathrm{~Hz}, 1 \mathrm{H}), 6.90(\mathrm{ddd}, J=8.0,7.0,1.1 \mathrm{~Hz}$, $1 \mathrm{H}), 7.06(\mathrm{~d}, J=2.1 \mathrm{~Hz}, 1 \mathrm{H}), 7.09(\mathrm{~d}, J=8.5 \mathrm{~Hz}, 1 \mathrm{H}), 7.34(\mathrm{~d}$, $J=8.9 \mathrm{~Hz}, 1 \mathrm{H}), 7.34(\mathrm{~d}, J=8.4 \mathrm{~Hz}, 1 \mathrm{H}), 7.48(\mathrm{~d}, J=8.5 \mathrm{~Hz}, 1$ H), $7.58(\mathrm{~d}, J=8.5 \mathrm{~Hz}, 1 \mathrm{H}), 7.78(\mathrm{~d}, J=8.5 \mathrm{~Hz}, 1 \mathrm{H}), 7.79(\mathrm{~d}, J$ $=8.5 \mathrm{~Hz}, 1 \mathrm{H}), 7.90(\mathrm{~d}, J=8.2 \mathrm{~Hz}, 1 \mathrm{H}), 7.96-8.06(\mathrm{~m}, 5 \mathrm{H}) \mathrm{ppm}$. ${ }^{13} \mathrm{C}$ NMR (101 MHz, $\mathrm{CDCl}_{3}$ ): $\delta=116.35$ (d), 118.06 (d), 118.30 (q), 123.70 (d), 124.25 (s), 124.33 (d), 124.77 (s), 125.13 (d), 125.95 (d), 126.26 (d), 126.76 (d), 126.82 (d), 127.09 (d), 127.26 (d), 127.30 (d), 127.39 (d), 127.47 (d), 127.58 (s), 127.76 (s), 127.83 (d), 128.01 (d), 128.81 (d), 128.90 (s), 130.15 (s), 130.77 (s), 131.19 (s), 131.22 (s), 131.71 (s), 132.06 (s), 132.33 (s), 146.19 (s) ppm. IR $\left(\mathrm{CHCl}_{3}\right)$ : $\tilde{\mathrm{v}}=3055(\mathrm{w}), 1623(\mathrm{w}), 1605(\mathrm{w}), 1580(\mathrm{vw}), 1557(\mathrm{vw}), 1515(\mathrm{w})$, 1499 (m), 1470 (w), 1421 (s), 1245 (s), 1142 (vs), 1007 (m), 878 (m), 849 (vs), 831 (w), 608 (m), 594 (w), $576(\mathrm{w}), 518(\mathrm{~m}), 503(\mathrm{w}) \mathrm{cm}^{-1}$. TOF MS (EI): $m / z(\%)=526(78)[\mathrm{M}]^{+}, 393(30), 375(100), 363$
(49), 350 (22), 337 (22), 324 (5), 300 (5), 287 (5), 181 (8), 149 (10). HRMS (EI): calcd. for $\mathrm{C}_{31} \mathrm{H}_{17} \mathrm{O}_{3} \mathrm{SF}_{3}$ 526.0851; found 526.0847.

Methyl [7]Helicene-2-carboxylate (9): A Schlenk flask was charged with [7]helicen-2-yl triflate (8) $(25 \mathrm{mg}, 0.047 \mathrm{mmol}),\left[\mathrm{Pd}(\mathrm{OAc})_{2}\right]$ (2.1 mg, $0.0094 \mathrm{mmol}, 20 \mathrm{~mol}-\%$ ) and 1,3-bis(diphenylphosphanyl) propane (3.9 mg, $0.0094 \mathrm{mmol}, 20 \mathrm{~mol}-\%)$, flushed with argon, and triethylamine $(17 \mu \mathrm{L}, 0.12 \mathrm{mmol}, 2.6$ equiv.) in DMSO $(1.5 \mathrm{~mL})$ and methanol $(1 \mathrm{~mL})$ was added. Carbon monoxide gas was then bubbled through the solution for $2 \mathrm{~min}$, and the reaction mixture was heated to $70{ }^{\circ} \mathrm{C}$ under $\mathrm{CO}$ (balloon) overnight. Water $(10 \mathrm{~mL})$ was added, the mixture was extracted with chloroform $(3 \times 5 \mathrm{~mL})$, and the combined fractions were dried with anhydrous $\mathrm{MgSO}_{4}$. After evaporation in vacuo, the crude residue was purified by flash chromatography on silica gel (heptane/ethyl acetate, 100:0 to 80:20) to give helicene methyl ester $9(15 \mathrm{mg}, 71 \%)$ as a yellow waxy solid. ${ }^{1} \mathrm{H}$ NMR (400 MHz, $\left.\mathrm{CDCl}_{3}\right): \delta=3.73(\mathrm{~s}, 3 \mathrm{H}), 6.40$ (ddd, $J=8.4$, $6.9,1.2 \mathrm{~Hz}, 1 \mathrm{H}), 6.89(\mathrm{ddd}, J=8.0,6.9,1.1 \mathrm{~Hz}, 1 \mathrm{H}), 7.18(\mathrm{~d}, J$ $=8.5 \mathrm{~Hz}, 1 \mathrm{H}), 7.29(\mathrm{~d}, J=7.8 \mathrm{~Hz}, 1 \mathrm{H}), 7.31(\mathrm{~d}, J=8.5 \mathrm{~Hz}, 1$ H), $7.44(\mathrm{~d}, J=8.5 \mathrm{~Hz}, 1 \mathrm{H}), 7.50(\mathrm{dd}, J=8.4,1.2 \mathrm{~Hz}, 1 \mathrm{H}), 7.50$ $(\mathrm{d}, J=8.3 \mathrm{~Hz}, 1 \mathrm{H}), 7.65(\mathrm{~d}, J=8.5 \mathrm{~Hz}, 1 \mathrm{H}), 7.82(\mathrm{~d}, J=8.5 \mathrm{~Hz}$, $1 \mathrm{H}), 7.92(\mathrm{~d}, J=8.4 \mathrm{~Hz}, 1 \mathrm{H}), 7.94(\mathrm{~d}, J=8.4 \mathrm{~Hz}, 1 \mathrm{H}), 7.99$ $8.07(\mathrm{~m}, 5 \mathrm{H}) \mathrm{ppm} .{ }^{13} \mathrm{C} \mathrm{NMR}\left(101 \mathrm{MHz}, \mathrm{CDCl}_{3}\right): \delta=51.30(\mathrm{q})$, 123.77 (d), 124.01 (d), 124.63 (d), 124.82 (s), 124.98 (d), 125.07 (s), 125.11 (s), 125.63 (d), 126.54 (d), 126.71 ( $2 \times$ d), 126.73 (d), 126.93 (d), 127.06 (d), 127.09 (d), 127.21 (d), 127.26 (d), $127.40(2 \times d)$, 127.51 (s), 128.25 (d), 128.53 (s), 128.62 (s), 129.17 (s), 130.87 (s), 131.57 (s), 131.64 (s), 132.11 (s), 132.26 (s), 134.17 (s), 166.70 (s) ppm. IR $\left(\mathrm{CHCl}_{3}\right): \tilde{v}=3054(\mathrm{w}), 1713(\mathrm{vs}), 1619(\mathrm{w}), 1609(\mathrm{w}), 1577$ (vw), 1552 (vw), 1520 (w), 1494 (w), 1438 (m), 1270 (m), 1258 (m), 1246 (m), 1123 (m), 853 (s), 841 (s) $\mathrm{cm}^{-1}$. MS (ESI): $\mathrm{m} / \mathrm{z}=459[\mathrm{M}$ $+\mathrm{Na}^{+}$. TOF MS (EI): $\mathrm{m} / z(\%)=436(100)[\mathrm{M}]^{+}, 374(35), 350$ (8), 300 (7), 187 (5). HRMS (EI): calcd. for $\mathrm{C}_{32} \mathrm{H}_{20} \mathrm{O}_{2} 436.1463$; found 436.1459 .

[7]Helicene-2-carboxylic Acid (10): A tube was charged with sodium methoxide solution [prepared by dissolving sodium (120 mg, $5.3 \mathrm{mmol}, 100$ equiv.) in wet methanol $(3 \mathrm{~mL})$ under argon], and methyl [7]helicene-2-carboxylate (9) (23 mg, $0.053 \mathrm{mmol}$ ) was added. The tube was sealed and heated to $80^{\circ} \mathrm{C}$ for $24 \mathrm{~h}$. After cooling, the solution was concentrated in vacuo, acidified with $1 \mathrm{M}$ hydrochloric acid and extracted with dichloromethane $(3 \times 5 \mathrm{~mL})$. The combined organic portions were dried with anhydrous $\mathrm{MgSO}_{4}$, concentrated in vacuo to dryness, and the residue was further dried in vacuo $(<50 \mathrm{~Pa})$ for $3 \mathrm{~h}$ to give helicenecarboxylic acid $\mathbf{1 0}(22 \mathrm{mg}$, $99 \%)$ as a yellow solid. ${ }^{1} \mathrm{H}$ NMR $\left(600 \mathrm{MHz}, \mathrm{CDCl}_{3}\right): \delta=6.41$ (ddd, $J=8.4,6.8,1.4 \mathrm{~Hz}, 1 \mathrm{H}), 6.90$ (ddd, $J=8.0,6.8,1.2 \mathrm{~Hz}, 1$ $\mathrm{H}), 7.17$ (ddt, $J=8.4,1.2,0.7,0.7 \mathrm{~Hz}, 1 \mathrm{H}$ ), 7.30 (ddt, $J=8.0$, 1.4, 0.7, $0.7 \mathrm{~Hz}, 1 \mathrm{H}), 7.33(\mathrm{dt}, J=8.3,0.6,0.6 \mathrm{~Hz}, 1 \mathrm{H}), 7.46(\mathrm{dt}$, $J=8.4,0.7,0.7 \mathrm{~Hz}, 1 \mathrm{H}), 7.50(\mathrm{dd}, J=8.3,1.7 \mathrm{~Hz}, 1 \mathrm{H}), 7.51$ (ddd, $J=8.4,0.8,0.6 \mathrm{~Hz}, 1 \mathrm{H}), 7.68(\mathrm{dd}, J=8.4,0.5 \mathrm{~Hz}, 1 \mathrm{H})$, $7.84(\mathrm{dd}, J=8.4,0.6 \mathrm{~Hz}, 1 \mathrm{H}), 7.93(\mathrm{dd}, J=8.1,0.6 \mathrm{~Hz}, 1 \mathrm{H}), 7.94$ $(\mathrm{dd}, J=8.1,0.6 \mathrm{~Hz}, 1 \mathrm{H}), 8.01(\mathrm{ddd}, J=1.7,0.9,0.5 \mathrm{~Hz}, 1 \mathrm{H})$, $8.01(\mathrm{dd}, J=8.1,0.5 \mathrm{~Hz}, 1 \mathrm{H}), 8.04(\mathrm{dd}, J=8.1,0.5 \mathrm{~Hz}, 1 \mathrm{H}), 8.05$ $(\mathrm{dd}, J=8.1,0.5 \mathrm{~Hz}, 1 \mathrm{H}), 8.07(\mathrm{dd}, J=8.1,0.5 \mathrm{~Hz}, 1 \mathrm{H}) \mathrm{ppm} .{ }^{13} \mathrm{C}$ NMR (151 MHz, $\left.\mathrm{CDCl}_{3}\right): \delta=123.56$ (d), 123.81 (d), 124.63 (d), 124.77 (d), 124.83 (s), 124.87 (2× s), 126.04 (d), 126.39 (d), 126.52 (d), 126.53 (d), 126.54 (d), 126.71 (d), 126.73 (d), 127.02 (d), 127.10 (d), 127.17 (d), 127.22 (s), 127.24 (d), 127.60 (d), 128.12 (d), 128.47 (s), 128.48 (s), 128.93 (s), 130.70 (s), 131.43 (s), 131.49 (s), 131.90 (s), 132.05 (s), 134.11 (s), 168.68 (s) ppm. IR $\left(\mathrm{CHCl}_{3}\right): \tilde{v}=3527$ (m), 3054 (m), 2650 (vw), 2520 (vw), 1723 (m), 1685 (m), 1617 (m), 1603 (m), 1578 (w), 1560 (w), $1521(\mathrm{w}), 1491(\mathrm{vw}), 1467$ (w), 1437 (w), $853(\mathrm{~m}), 838(\mathrm{~m}) \mathrm{cm}^{-1}$. ESI MS: $m / z=421[\mathrm{M}-\mathrm{H}]^{-}$. TOF MS (EI): $m / z(\%)=422(100)[\mathrm{M}]^{+\cdot}, 374(38), 350(13), 300(13)$, 
242 (30), 187 (13), 165 (13), 149 (50), 104 (5), 73 (5). HRMS (EI): calcd. for $\mathrm{C}_{31} \mathrm{H}_{18} \mathrm{O}_{2}$ 422.1307; found 422.1312 .

Separation of Racemic [7]Helicene-2-carboxylic Acid (10) into Enantiomers: Racemic $10(3 \mathrm{mg})$ was resolved by repeated HPLC separation on a Chirallica PST-4 analytical column $(250 \mathrm{~mm} \times 4.6 \mathrm{~mm}, 5 \mu \mathrm{m})$ by using an Agilent 1100 Series preparative instrument (heptane/2-propanol, 95:5; flow rate $0.6 \mathrm{~mL} / \mathrm{min}$; injections $0.2 \mathrm{mg} / 250 \mu \mathrm{L}$, total 15 injections). Evaporation of the solvents gave optically pure $(-)-\mathbf{1 0}\left[1 \mathrm{mg}, t_{\mathrm{r}}=20.5 \mathrm{~min},[\alpha]_{589}^{20}=\right.$ $\left.-3.085\left(c=0.042, \mathrm{CHCl}_{3}\right)\right]$ and $(+)-\mathbf{1 0}\left[1 \mathrm{mg}, t_{\mathrm{r}}=40.6 \mathrm{~min},[\alpha]_{589}^{20}\right.$ $\left.=+3.191\left(c=0.048, \mathrm{CHCl}_{3}\right)\right]$. HPLC analyses of nonracemic 10 were performed with an analytical Varian HPLC instrument by using the same column (heptane/2-propanol, 95:5; flow rate $0.6 \mathrm{~mL} / \mathrm{min}$ ) with simultaneous UV detection at $254 \mathrm{~nm}$ (Varian) and polarimetric detection (Chiralizer, Knauer). M.p. of (+)-10 $>290{ }^{\circ} \mathrm{C}$ (dec.), crystallised from acetonitrile.

[7]Helicene-2-carbonitrile (11). Method A (from Helicenyl Triflate 8): To a solution of [7]helicen-2-yl triflate $(\mathbf{8})(25 \mathrm{mg}, 0.047 \mathrm{mmol})$, [Pd(OAc) $)_{2}$ (2.1 mg, $\left.0.0094 \mathrm{mmol}, 20 \mathrm{~mol}-\%\right)$, 1,3-bis(diphenylphosphanyl)propane $(3.9 \mathrm{mg}, \quad 0.0094 \mathrm{mmol}, \quad 20 \mathrm{~mol}-\%)$ and $N, N, N^{\prime}, N^{\prime}$-tetramethylethylene-1,2-diamine $(14 \mu \mathrm{L}, 0.094 \mathrm{mmol}$, 2.0 equiv.) in toluene $(1.5 \mathrm{~mL})$, a solution of trimethylsilyl cyanide (12 $\mu \mathrm{L}, 0.094 \mathrm{mmol}, 2.0$ equiv.) in toluene $(1 \mathrm{~mL})$ was slowly added by means of a syringe pump $(0.25 \mathrm{~mL} / \mathrm{h})$ at $100{ }^{\circ} \mathrm{C}$ during $4 \mathrm{~h}$. After evaporation of toluene in vacuo, the product was separated from the unreacted starting material (conversion only $36 \%$ according to ${ }^{1} \mathrm{H}$ NMR spectroscopic analysis) by flash chromatography on silica gel (heptane/ethyl acetate, 80:20) to give helicene nitrile $11(1.0 \mathrm{mg}$, $5 \% ; 15 \%$ based on consumed starting material) as a yellow oil. Method B (via [7]Helicene-2-carboxamide): [7]Helicene-2-carboxylic acid (10) (22 mg, $0.052 \mathrm{mmol}$ ) was suspended in thionyl chloride $(3 \mathrm{~mL})$ and heated together with a drop of DMF to $80^{\circ} \mathrm{C}$ for $2 \mathrm{~h}$ in a sealed tube. After cooling in an ice bath, the reaction was quenched dropwise with aqueous ammonia solution $(10 \mathrm{~mL})$. Extraction with dichloromethane $(3 \times 10 \mathrm{~mL})$, washing with water $(10 \mathrm{~mL})$, drying with anhydrous $\mathrm{MgSO}_{4}$, and concentration in vacuo afforded a dark oil, which was purified by chromatography on silica gel (dichloromethane/methanol, 100:0 to 98:2). The yellow semi-solid obtained contained, besides [7]helicene-2-carboxamide (14 mg, 64\%), inseparable impurities and was therefore used in the next stage without further purification. Crude [7]helicene-2-carboxamide $(14 \mathrm{mg}, 0.033 \mathrm{mmol})$ and triethylamine $(93 \mu \mathrm{L}, 0.66 \mathrm{mmol}$, 20 equiv.) were dissolved in dichloromethane $(2 \mathrm{~mL})$ under argon, and triflic anhydride $(56 \mu \mathrm{L}, 0.33 \mathrm{mmol}, 10$ equiv.) was added dropwise at $0{ }^{\circ} \mathrm{C}$. The mixture was warmed to room temp. and stirred for $2 \mathrm{~h}$. After evaporation of the solvent in vacuo, the product was isolated by flash chromatography on silica gel (toluene). Further purification was achieved by preparative HPLC on C-18 RP silica gel (methanol/water, 50:50 to 100:0) to give helicene nitrile $\mathbf{1 1}$ $(2.5 \mathrm{mg}, 19 \%)$ as a yellow oil. ${ }^{1} \mathrm{H}$ NMR $\left(600 \mathrm{MHz}, \mathrm{CDCl}_{3}\right): \delta=$ 6.40 (ddd, $J=8.4,6.8,1.4 \mathrm{~Hz}, 1 \mathrm{H}), 6.91(\mathrm{ddd}, J=8.0,6.8,1.2 \mathrm{~Hz}$, $1 \mathrm{H}), 7.06(\mathrm{dd}, J=8.2,1.5 \mathrm{~Hz}, 1 \mathrm{H}), 7.12(\mathrm{ddt}, J=8.4,1.2,0.7$, $0.7 \mathrm{~Hz}, 1 \mathrm{H}$ ), 7.34 (ddt, $J=8.0,1.4,0.7,0.7 \mathrm{~Hz}, 1 \mathrm{H}), 7.35$ (dt, $J$ $=8.2,0.7,0.7 \mathrm{~Hz}, 1 \mathrm{H}), 7.50(\mathrm{dt}, J=8.4,0.7,0.7 \mathrm{~Hz}, 1 \mathrm{H}), 7.57$ $(\mathrm{dt}, J=1.5,0.7,0.7 \mathrm{~Hz}, 1 \mathrm{H}), 7.61(\mathrm{dt}, J=8.4,0.7,0.7 \mathrm{~Hz}, 1 \mathrm{H})$, $7.886(\mathrm{dd}, J=8.4,0.5 \mathrm{~Hz}, 1 \mathrm{H}), 7.889(\mathrm{~d}, J=8.4 \mathrm{~Hz}, 1 \mathrm{H}), 7.94$ $(\mathrm{dd}, J=8.1,0.6 \mathrm{~Hz}, 1 \mathrm{H}), 8.03(\mathrm{~d}, J=8.3 \mathrm{~Hz}, 1 \mathrm{H}), 8.04(\mathrm{~d}, J=$ $8.3 \mathrm{~Hz}, 1 \mathrm{H}), 8.06(\mathrm{dd}, J=8.1,0.5 \mathrm{~Hz}, 1 \mathrm{H}), 8.09(\mathrm{dd}, J=8.1$, $0.5 \mathrm{~Hz}, 1 \mathrm{H}), 8.10(\mathrm{~d}, J=8.1 \mathrm{~Hz}, 1 \mathrm{H}) \mathrm{ppm} .{ }^{13} \mathrm{C} \mathrm{NMR}(151 \mathrm{MHz}$, $\left.\mathrm{CDCl}_{3}\right): \delta=106.69$ (s), 119.00 (s), 123.85 (d), 124.06 (d), 124.53 (s), 124.72 (s), 125.12 (d), 125.87 (d), 126.35 (d), 126.51 (d), 126.80 (d), 126.84 (d), 127.09 (d), 127.12 (d), 127.36 (s), 127.36 (d), 127.48 (s), 127.56 (d), 127.63 (d), 128.16 (d), 128.22 (d), 128.56 (s), 128.82 (s), 129.13 (d), 129.81 (d), 131.11 (s), 131.39 (s), 131.72 (s), 132.23 (s), 132.43 (s), 133.33 (s) ppm. IR $\left(\mathrm{CHCl}_{3}\right): \tilde{v}=3056(\mathrm{w}), 2228(\mathrm{~m})$, 1618 (w), 1608 (w), 1515 (vw), 1493 (w), 1466 (w), 1436 (vw), 851 (vs), 840 (s), 828 (w), 541 (w) $\mathrm{cm}^{-1}$. MS (APCI): $\mathrm{m} / \mathrm{z}=426[\mathrm{M}+$ $\mathrm{Na}^{+}, 404[\mathrm{M}+\mathrm{H}]^{+}$. TOF MS (EI): $m / z(\%)=403(100)[\mathrm{M}]^{+*}, 375$ (23), 362 (5), 300 (8), 187 (5), 149 (18). HRMS (EI): calcd. for $\mathrm{C}_{31} \mathrm{H}_{17} \mathrm{~N} 403.1361$; found 403.1357.

Supporting Information (see footnote on the first page of this article): Copies of the ${ }^{1} \mathrm{H}$ and ${ }^{13} \mathrm{C}$ NMR spectra of compounds 3-11.

\section{Acknowledgments}

This research was supported by the European Commission under Grant No. FP6-015847, by the Czech Science Foundation under Grant No. P207/10/2207, by the Ministry of Education, Youth and Sports of the Czech Republic under Project No. LC512 (the Centre for Biomolecules and Complex Molecular Systems) and by the Institute of Organic Chemistry and Biochemistry, Academy of Sciences of the Czech Republic (part of the Research Project Z4 055 0506). Dr. Jana Vacek Chocholoušová and Dr. Jaroslav Vacek are acknowledged for calculating dipole moments.

[1] For a discussion on these terms, see: S. Grimme, Angew. Chem. Int. Ed. 2008, 47, 3430-3434.

[2] a) P. Hobza, K. Müller-Dethlefs, Non-Covalent Interactions: Theory and Experiment, Royal Society of Chemistry, Cambridge, 2010; b) C. A. Schalley, A. Springer, Mass Spectrometry of Non-Covalent Complexes: Supramolecular Chemistry in the Gas Phase, Wiley, Hoboken, 2009.

[3] J. Černý, M. Kabeláč, P. Hobza, J. Am. Chem. Soc. 2008, 130, 16055-16059.

[4] Organic Electronics (Ed.: H. Klauk), Wiley-VCH, Weinheim, 2006.

[5] $\mathrm{TTF}=$ tetrathiafulvalene, TCNQ = tetracyanoquinodimethane; a) D. Jérome, Chem. Rev. 2004, 104, 5565-5591; b) J. Ferraris, D. Cowan, W. Walatka, J. Perlstein, J. Am. Chem. Soc. 1973, 95, 948-949.

[6] T. Kelley in Organic Electronics (Ed.: H. Klauk), Wiley-VCH, Weinheim, 2006, pp. 35-57.

[7] a) I. G. Stará, I. Starý in Science of Synthesis (Ed.: J. S. Siegel), Thieme, Stuttgart, 2010, vol. 45b, pp. 885-953; b) I. Starý, I. G. Stará in Strained Hydrocarbons (Ed.: H. Dodziuk), WileyVCH, Weinheim, 2009, pp. 166-176; c) A. Rajca, M. Miyasaka in Functional Organic Materials (Eds.: T. J. J. Müller, U. H. F. Bunz), Wiley-VCH, Weinheim, 2007, pp. 547-581; d) A. Urbano, Angew. Chem. Int. Ed. 2003, 42, 3986-3989; e) H. Hopf in Classics in Hydrocarbon Chemistry: Syntheses, Concepts, Perspectives, Wiley-VCH, Weinheim, 2000, pp. 323-330; f) T. J. Katz, Angew. Chem. Int. Ed. 2000, 39, 1921-1923.

[8] C. Nuckolls, T. J. Katz, G. Katz, P. J. Collings, L. Castellanos, J. Am. Chem. Soc. 1999, 121, 79-88.

[9] C. Nuckolls, T. J. Katz, J. Am. Chem. Soc. 1998, 120, 95419544.

[10] a) R. Fasel, M. Parschau, K.-H. Ernst, Nature 2006, 439, 449452; b) K.-H. Ernst, Y. Kuster, R. Fasel, M. Müller, U. Ellerbeck, Chirality 2001, 13, 675-678; c) R. Fasel, A. Cossy, K.-H. Ernst, F. Baumberger, T. Greber, J. Osterwalder, J. Chem. Phys. 2001, 115, 1020-1027.

[11] K.-H. Ernst, M. Neuber, M. Grunze, U. Ellerbeck, J. Am. Chem. Soc. 2001, 123, 493-495.

[12] K.-H. Ernst, M. Böhringer, C. F. McFadden, P. Hug, U. Müller, U. Ellerbeck, Nanotechnology 1999, 10, 355-361.

[13] M. Taniguchi, H. Nakagawa, A. Yamagishi, K. Yamada, $J$. Mol. Catal. A 2003, 199, 65-71.

[14] C. Kim, T. J. Marks, A. Facchetti, M. Schiavo, A. Bossi, S. Maiorana, E. Licandro, F. Todescato, S. Toffanin, M. Muccini, C. Graiff, A. Tiripicchio, Org. Electron. 2009, 10, 1511-1520. 
[15] a) P. Sehnal, I. G. Stará, D. Šaman, M. Tichý, J. Míšek, J. Cvačka, L. Rulíšek, J. Chocholoušová, J. Vacek, G. Goryl, M. Szymonski, I. Císařová, I. Starý, Proc. Natl. Acad. Sci. USA 2009, 106, 13169-13174; b) M. Miyasaka, A. Rajca, M. Pink, S. Rajca, J. Am. Chem. Soc. 2005, 127, 13806-13807.

[16] G. Treboux, P. Lapstun, Z. H. Wu, K. Silverbrook, Chem. Phys. Lett. 1999, 301, 493-497.

[17] M. M. S. Abdel-Mottaleb, E. Gomar-Nadal, M. Surin, H. Ujii, W. Mamdouh, J. Veciana, V. Lemaur, C. Rovira, J. Cornil, R. Lazzaroni, D. B. Amabilino, S. De Feyter, F. C. De Schryver, J. Mater. Chem. 2005, 15, 4601-4615.

[18] J. Puigmartí-Luis, A. Minoia, H. Uji-i, C. Rovira, J. Cornil, S. De Feyter, R. Lazzaroni, D. B. Amabilino, J. Am. Chem. Soc. 2006, 128, 12602-12603.

[19] P. Rahe, M. Nimmrich, A. Greuling, J. Schütte, I. G. Stará, J. Rybáček, G. Huerta-Angeles, I. Starý, M. Rohlfing, A. Kühnle, J. Phys. Chem. C 2010, 114, 1547-1552.

[20] M. Corsane, N. Defay, R. H. Martin, Bull. Soc. Chim. Belg. 1985, 94, 215-232.

[21] L. Owens, C. Thilgen, F. Diederich, C. B. Knobler, Helv. Chim. Acta 1993, 76, 2757-2774

[22] M. Joly, N. Defay, R. H. Martin, J. P. Declerq, G. Germain, B. Soubrier-Payen, M. Van Meerssche, Helv. Chim. Acta 1977, 60, 537-560.

[23] a) L. Liu, B. Yang, T. J. Katz, M. K. Poindexter, J. Org. Chem. 1991, 56, 3769-3775; b) F. B. Mallory, C. W. Mallory, Org. React. 1984, 30, 1-456.

[24] a) I. G. Stará, Z. Alexandrová, F. Teplý, P. Sehnal, I. Starý, D. Šman, M. Buděšínský, J. Cvačka, Org. Lett. 2005, 7, 25472550; b) F. Teplý, I. G. Stará, I. Starý, A. Kollárovič, D. Šaman, L. Rulíšek, P. Fiedler, J. Am. Chem. Soc. 2002, 124, 9175-
9180; c) I. G. Stará, I. Starý, A. Kollárovič, F. Teplý, Š. Vyskočil, D. Saman, Tetrahedron Lett. 1999, 40, 1993-1996; d) I. G. Stará, I. Starý, A. Kollárovič, F. Teplý, D. Šaman, M. Tichý, J. Org. Chem. 1998, 63, 4046-4050.

[25] F. Teplý, I. G. Stará, I. Starý, A. Kollárovič, D. Luštinec, Z. Krausová, D. Šaman, P. Fiedler, Eur. J. Org. Chem. 2007, 4244 4250.

[26] F. Teplý, I. G. Stará, I. Starý, A. Kollárovič, D. Šaman, P. Fiedler, S. Vyskočil, J. Org. Chem. 2003, 68, 5193-5197.

[27] J. Míšek, F. Teplý, I. G. Stará, M. Tichý, D. Šaman, I. Císařová, P. Vojtíšek, I. Starý, Angew. Chem. Int. Ed. 2008, 47, 3188-3191.

[28] P. Sehnal, Z. Krausová, F. Teplý, I. G. Stará, I. Starý, L. Rulíšek, D. Šaman, I. Císařová, J. Org. Chem. 2008, 73, 2074-2082.

[29] a) M. Sundermeier, A. Zapf, M. Beller, Eur. J. Inorg. Chem. 2003, 3513-3526; b) M. Sundermeier, S. Mutyala, A. Zapf, A. Spannenberg, M. Beller, J. Organomet. Chem. 2003, 684, 50 55.

[30] Z. Alexandrová, P. Sehnal, I. G. Stará, I. Starý, D. Šaman, S. G. Urquhart, E. Otero, Collect. Czech. Chem. Commun. 2006, 71, 1256-1264.

[31] T. Bürgi, A. Urakawa, B. Behzadi, K.-H. Ernst, A. Baiker, New J. Chem. 2004, 28, 332-334.

[32] R. H. Martin, M. J. Marchant, Tetrahedron 1974, 30, 343-345.

[33] a) M. Gdaniec, W. Jankowski, M. J. Milewska, T. Połoński, Angew. Chem. 2003, 115, 4033-4036; b) P. Holý, J. Závada, J. Podlaha, I. Císařová, Angew. Chem. Int. Ed. 1999, 38, 381-383.

[34] a) Y.-J. Han, J. Aizenberg, Angew. Chem. Int. Ed. 2003, 42, 3668-3670; b) J. Aizenberg, A. J. Black, G. M. Whitesides, Nature 1999, 398, 495-498.

Received: August 6, 2010

Published Online: December 9, 2010 